\title{
Uitvindingen of oplossingen
}

\author{
Maureen Limpens
}

(C) Bohn Stafleu van Loghum is een imprint van Springer Media B.V., onderdeel van Springer Nature 2018

Soms zie je een uitvinding voorbijkomen, waarvan je denkt, waarom is dit niet eerder bedacht? Wel eens gekeken naar Make me a millionaire inventor? Een programma van RTL-Z waarin men het verhaal zoekt achter uitvindingen waar ooit patent op is aangevraagd, maar verder niets mee is gebeurd. De bedenker wordt opgespoord en krijgt ondersteuning om het concept alsnog uit te werken. Zo ook de bedenker van de Glide Cycle. Een soort (hard)loopfiets die wel een frame heeft, maar dan een frame dat je bij het lopen niet in de weg zit, omdat het in een hoge boog over de gebruiker heen loopt. Op de plaats van het frame bij een gewone fiets, zit nu het zadel, dat met een soort straps bevestigd is aan het boogframe. De gebruiker lijkt op een koorddanser, die niet staat, maar zit. Comfortabel, op zijn iets doorbuigend koord, met de voeten net aan de grond. Daardoor kan hij zichzelf voortbewegen, zonder druk van het eigen lichaamsgewicht.

Op internet zoekend, zag ik dat de fiets inmiddels in productie is genomen. In eerste instantie wilde de bedenker zich alleen richten op revalidatiecentra, op mensen die na ziekte of een ongeluk weer moeten leren lopen. De toepassing is echter veel ruimer. Veel sporters die weer gaan trainen na een blessure - of die vanwege knieklachten genoodzaakt waren te stoppen met hun sport - pakken de draad weer op door met deze fiets te gaan trainen. Maar ook mensen die om welke reden dan ook weinig bewegen, worden enthousiast van de fiets. Hoe kwam de bedenker tot zijn uitvinding? Zijn hoogbejaarde moeder verbleef in een instelling, waar ze het grootste deel van de dag in een stoel voor zich uit zat te staren. Lopen kon ze alleen nog maar in een soort tilharnas, maar wat knapte ze daar dan van op. Weg was haar passiviteit. Bewegen deed haar goed. Hij wilde iets ontwikkelen waarmee mensen gemakkelijker konden bewegen en uiteindelijk hebben heel veel mensen profijt van deze uitvinding.

Is het mijn bedoeling om deze uitvinding te promoten? Nee. Ik wil het wat dichter bij huis houden. Ook binnen de podotherapie zijn er mensen die inventief zijn, die een oplossing hebben bedacht, groot of klein, voor een terugkerend probleem waarmee ze zelf of hun patiënt te maken krijgen. Ik ben benieuwd naar die oplossingen. Kunnen ze op grotere schaal worden ingezet, zodat meer mensen er profijt van hebben?

Hierbij roep ik iedereen op die een grote of kleine oplossing voor iets bedacht heeft, dit te melden bij de redactie, zodat de hele beroepsgroep en patiënten er profijt van kunnen hebben.

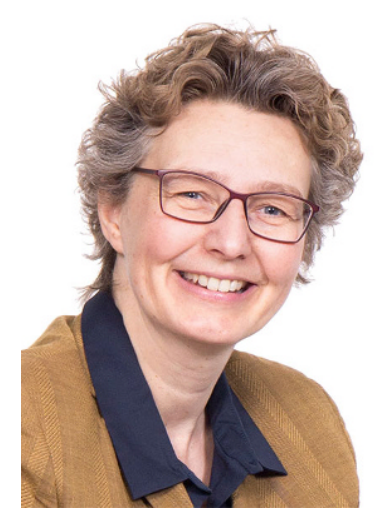

Maureen Limpens, hoofdredacteur 